\title{
SEDIMENT YIELD ESTIMATES IN NORTH-WESTERN GREECE AND ANALYSES WITH HYDROLOGIC AND GEOMORPHOLOGIC FACTORS
}

\author{
Zarris D. ${ }^{1}$, Lykoudi E. ${ }^{2}$, and Panagoulia D. ${ }^{1}$ \\ ${ }^{\prime}$ Department of Water Resources, School of Civil Engineering, National Technical University of \\ Athens, 5 Heroon Polytechneiou St., 15780, Athens, Greece, zarris@itia.ntua.gr, \\ dpanag@central.ntua.gr \\ ${ }^{2}$ Department of Geological Sciences, School of Mining Engineering and Metallurgy, National \\ Technical University of Athens, 5 Heroon Polytechneiou St., 15780, Athens, Greece, \\ mmgpel@central.ntua.gr,elykoudi@metal.ntua.gr
}

\begin{abstract}
Erosion and sediment yield form a crucial issue within the integrated water resources management context; however are often neglected during the design of major water systems. Sediment yields in 11 river catchments in North-Western Greece are computed with the application of the mean daily discharges to the sediment discharge rating curves and compared to the earlier estimates published by other researchers. For these catchments a number of hydrologic and geomorphologic parameters have been computed using advanced mapping methodologies. An attempt is made to correlate the suspended sediment estimates mainly with geomorphologic parameters, that rarely has been carried out in the international literature.
\end{abstract}

Key words: sediment yield, hydrology, geomorphology, Western Greece.

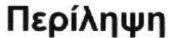

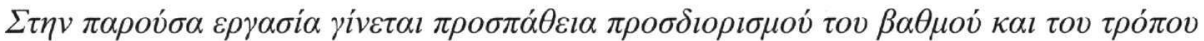

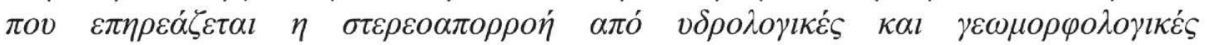

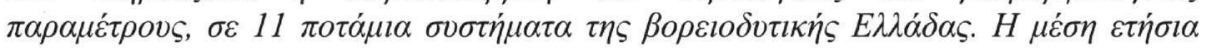

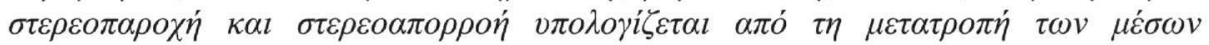

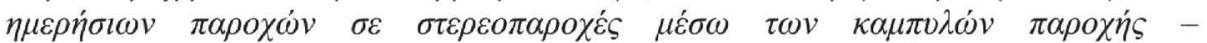

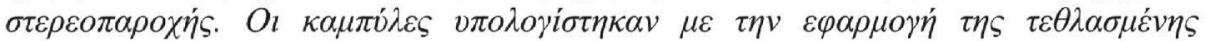

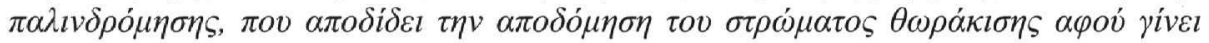

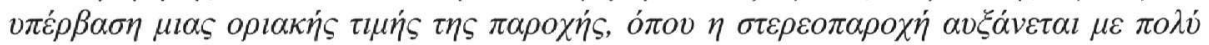
$\mu \varepsilon \gamma \alpha \lambda \dot{v} \tau \varepsilon \rho o \rho v \theta \mu o ́$.

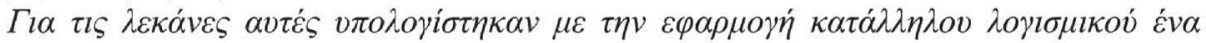

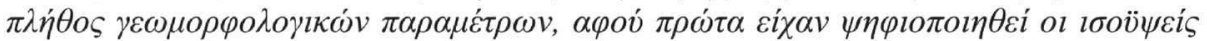

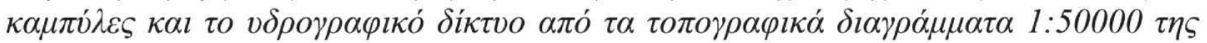

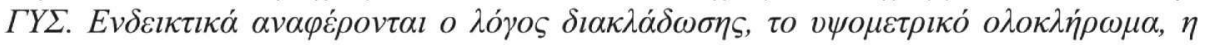

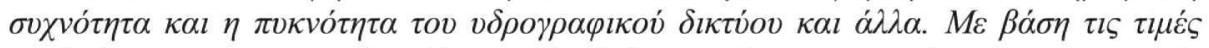

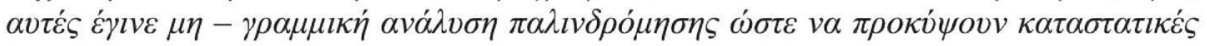

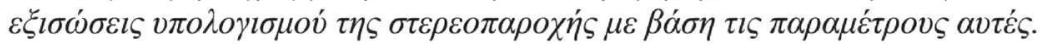




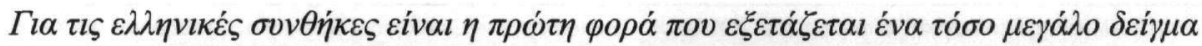

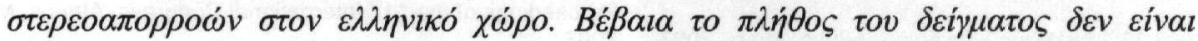

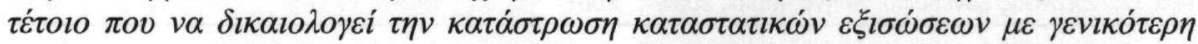

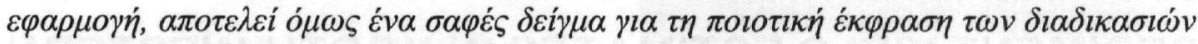

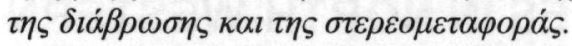

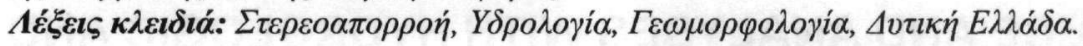

\section{Introduction}

Sediment yield is the sediment load normalized for the catchment area and is the net result of erosion and depositional processes within a basin. Thus, it is controlled by those factors that control erosion and sediment delivery, including local topography, soil properties, climate, vegetation cover, catchment morphology, drainage network characteristics and land use. Predicting the sediment discharge of a river section or the sediment yield of an upstream catchment has always been an ambitious goal for a number of different earth scientists, such as engineers, hydrologists, geomorphologists and others. In particular, estimation of sediment discharge is a vital key point for the assessment and design of major hydraulic systems, such as irrigation dams, hydroelectric projects and flood attenuation structures. It is estimated that throughout the world, there are probably more than a few million small ponds (up to several thousand cubic meters volume of stored water) (Verstraeten and Poesen 2000, de Vente et al. 2005) as well as 39000 large dams. At present, sediment yield estimates are achieved mainly from simple empirical models that relate mean annual sediment yield $\left(\mathrm{S}_{\mathrm{Y}}\right.$, in $\left.t / \mathrm{km}^{2}\right)$ to catchment properties, including drainage area, topography, climate and vegetation characteristics (e.g. Jansen and Painter 1974, Dendy and Bolton 1976, Walling 1983). Catchment sediment yield usually decreases with basin scale, mainly because sediment sinks, such as floodplains, will generally increase, assuming the concept of source - transport - deposition continuum as the ideal fluvial system.

The statistical expression of suspended sediment discharge and stream discharge is called a sediment discharge rating curve and most commonly takes the power-law form of:

\section{Equation 1 - Sediment discharge rating curve}

$$
Q_{s i}=a Q_{i}^{b} n_{i}
$$

where $Q$ s is the sediment discharge $(\mathrm{kg} / \mathrm{s}), Q$ is the river discharge $\left(\mathrm{m}^{3} / \mathrm{s}\right), a$ and $b$ are the sediment rating coefficient and exponent correspondingly, and $\eta$ is the multiplicative error term which exhibits a lognormal distribution (Ferguson 1986). The exponent parameter, $b$, is very important when determining the sediment yield of a catchment and it normally assigns values between 0.5 and 3; the higher the parameter the more intense transport capacity of the river flow. Estimates of sediment yield based on rating curve calculations will in most cases involve greater error than those obtained from direct measurements, and this can be ascribed primarily to the scatter associated with the rating relationship. Several researchers (Walling 1977, Asselman 2000) have analysed such scatter in detail and have described controls associated with season, water temperature, hysteretic effects related to rising and falling stage of the hydrograph, exhaustion effects and varying patterns of tributary inflow. The mathematical technique which is used to construct the rating curve and the adequacy of the number of data points have also been shown to be significant controls on the accuracy of resultant calculations of sediment yield. Walling (1977) shows that by using a single rating curve for the river Creedy in the UK may involve overestimation of the annual sediment discharge up to $60 \%$. 


\section{Methodology and Study Area}

\subsection{Catchment sediment yields in NW Greece}

The broken line interpolation was introduced by Koutsoyiannis (2000) as a simple alternative to numerical smoothing and interpolating methods and is treated here as a surrogate for the ordinary single rating curve. The main concept is to approximate a smooth curve that may be drawn for the data points with a broken line, which can be numerically estimated by means of a least squares fitting procedure. If the only objective used for fitting the broken line is the minimization of total square error then the result might be a very rough broken line, depending on the arrangement of the data points. However, the roughness of the broken line can be controlled by introducing as a second objective the minimization of the roughness. The broken line is a concatenation of straightline segments, where the number of the straight-line segments is numerically the outcome of the compromise between the two objectives of minimizing the fitting error and the roughness of the broken line. Considering that the prevailing fluvial form in upstream Greek rivers is the gravel-bed form, we assume a broken line with two segments. In such a fluvial form, there is a distinct threshold discharge for sediment motion, which is attributed to the development of the well-known armour layer. Below this threshold there is no exchange of the suspended sediment with the riverbed. Once the surface, coarse material, armour layer fully breaks up beyond the threshold discharge and exposes a larger range of particle sizes underneath, the transport rate significantly increases. Additionally, bank erosion during high discharges will enhance the sediment availability in the river bed.

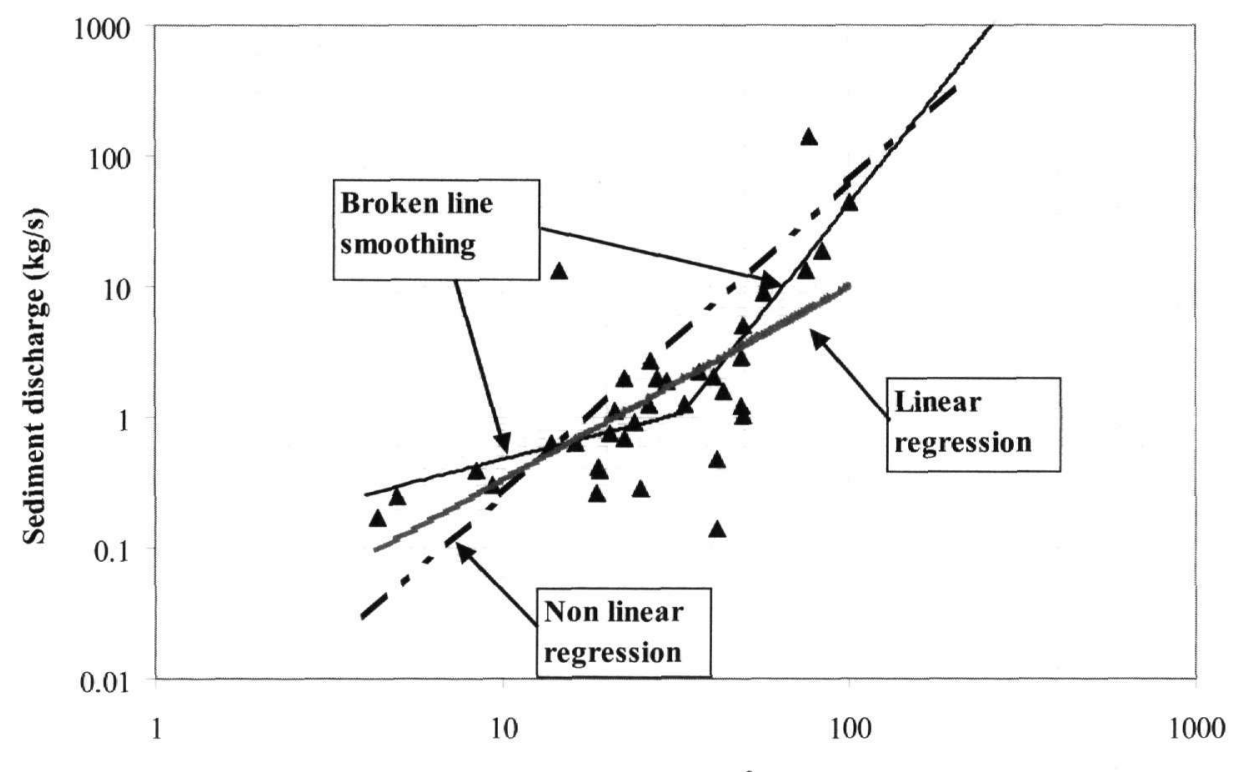

Discharge $\left(\mathrm{m}^{3} / \mathrm{s}\right)$

Figure 1 - Comparison of the broken line smoothing technique in contrast to the ordinary power curve and the non-linear regression for the Poros Riganiou cross section

Figure 1 shows an example of the broken line rating curve and the application of Equation 1 with the non-linear regression and the linear regression of the log-transformed variables $Q$ s and $Q$ and back-transformed to Equation 1 for the set of sediment discharge measurements for the Poros Riganiou cross section of the Evinos River. The broken line shows an excellent fit to the data in contrast to single rating curves for the whole set of measured discharges. Particularly for the linear regression of the log-transformed variables it is illustrated that for high discharges the rating curve 
significantly underestimates the sediment discharge of the measurements. The rating exponent, $b$, for this specific case is equal to 0.68 for the first segment and 3.3 for the steeper segment of the broken line.

\subsection{Study area}

11 river sites in North-Western Greece have been examined. The original suspended sediment measurements have been collected from the Public Power Corporation (PPC) and normally cover a time span from 1965 to 1980 . The number of measurements varies from site to site (e.g. 36 measurements at Poros Riganiou to 121 at Plaka Bridge) and the frequency of measurement is highly variable. The general map of the catchments and the associated cross sections is shown on Figure 2. Table 1 presents the general characteristics of the examined catchments. The mean annual suspended sediment discharge and sediment yield for cross sections 2, 3 and 4 have been resulted from the measurement of the Kremasta reservoir sedimentation rate (Zarris et al. 2002), whereas for the rest of the cross sections the rating curves have been constructed using the broken line interpolation method. Mean daily discharges are available for each of the remaining 8 cross sections for nearly the same period as the sediment discharge measurements (also available from the PPC). Therefore the mean annual sediment discharge and sediment yield have been computed and presented in Table 1.

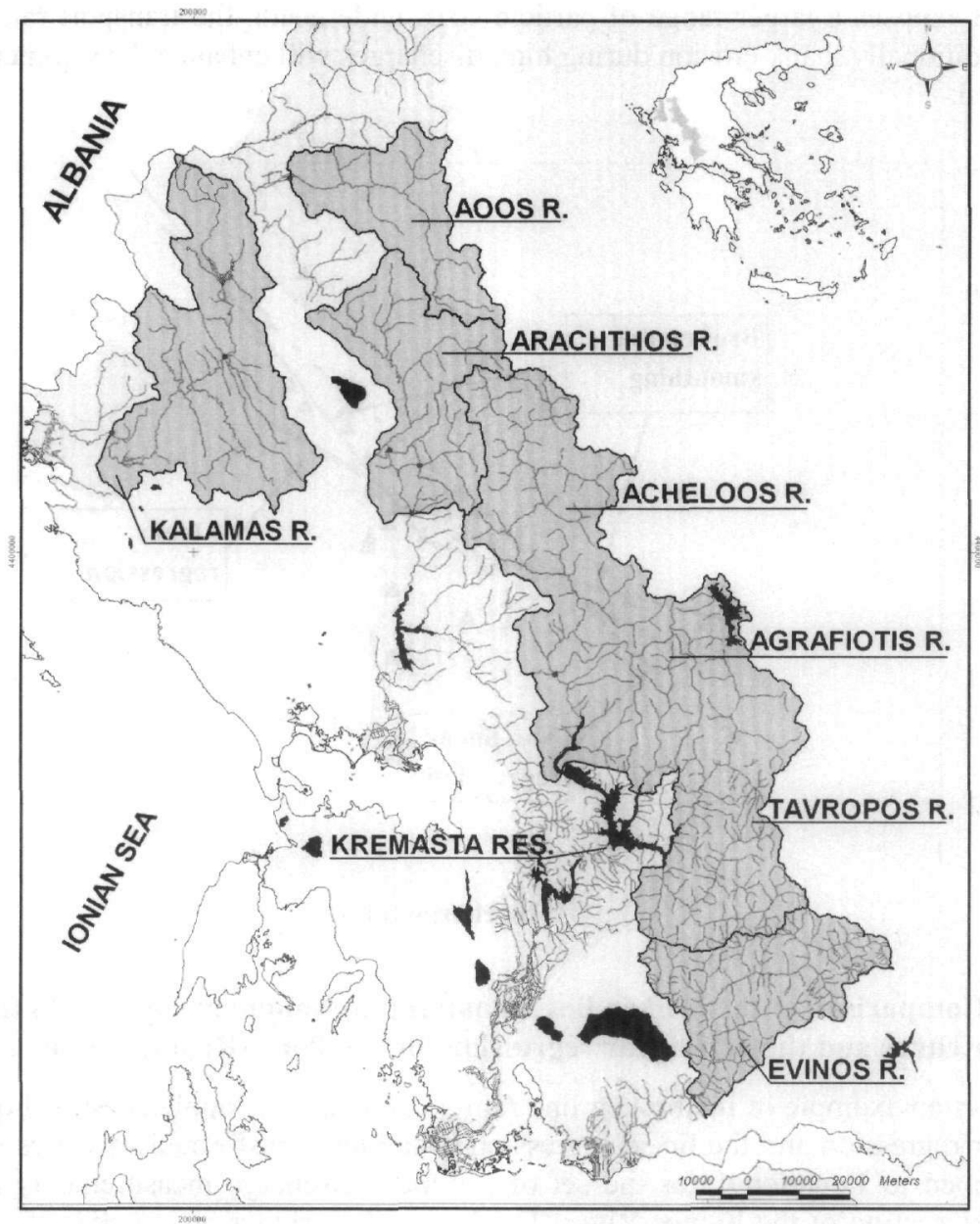

Figure 2 - Map of the study area 
Table 1 - Characteristic values of mean annual sediment discharge (Qs) and sediment yield (Sy) for the cross-sections under consideration

\begin{tabular}{|l|l|l|c|c|c|c|c|}
\hline No & \multicolumn{1}{|c|}{ River } & Cross Section & $\begin{array}{c}\text { Area } \\
\left(\mathbf{k m}^{\mathbf{2}}\right)\end{array}$ & $\begin{array}{c}\text { Qav } \\
\left(\mathbf{m}^{\mathbf{3}} / \mathbf{s}\right)\end{array}$ & $\begin{array}{c}\text { Qmax } \\
\left(\mathbf{m}^{\mathbf{3}} / \mathbf{s}\right)\end{array}$ & Qs $\mathbf{( k g / s )}$ & $\begin{array}{c}\text { Sy } \\
\left(\mathbf{t} / \mathbf{k m}^{\mathbf{2}} \mathbf{)}\right.\end{array}$ \\
\hline 1 & Acheloos & Avlaki & 1355 & 50.2 & 561.4 & 73.3 & 1706.0 \\
\hline 2 & Acheloos & Kremasta Res. & 1733 & - & - & 66.0 & 1201.0 \\
\hline 3 & Agrafiotis & Kremasta Res. & 320 & - & - & 20.9 & 2059.7 \\
\hline 4 & Tavropos & Kremasta Res. & 1239 & - & - & 19.5 & 496.3 \\
\hline 5 & Evinos & Poros Riganiou & 914 & 25.3 & 439.5 & 42.5 & 1466.4 \\
\hline 6 & Arachthos & Tsimovo Br. & 640 & 18.7 & 314.7 & 21.3 & 1049.6 \\
\hline 7 & Arachthos & Gogo Br. & 203 & 11.4 & 104.7 & 10.3 & 1600.1 \\
\hline 8 & Arachthos & Plaka Br. & 970 & 36.1 & 427.2 & 38.4 & 1248.4 \\
\hline 9 & Kalamas & Soulopoulo Br. & 660 & 22.7 & 130.2 & 5.9 & 281.9 \\
\hline 10 & Kalamas & Kioteki & 1481 & 48.9 & 419.2 & 25.4 & 540.9 \\
\hline 11 & Aoos & Konitsa Br. & 706 & 24.9 & 463.5 & 48.9 & 2184.3 \\
\hline
\end{tabular}

In order to assess factors affecting sediment yields in NW Greece, key catchment attributes related to erosion were collected. Contour and streams shown in topographic maps 1:50000 were digitized and the Digital Terrain Models (DTM) with cell size equal to $25 \mathrm{~m}$ were derived. Major topographic attributes such as the slope, the relief ratio, the bifurcation ratio and the hypsometric integral have been computed using the RiverTools 3.0 software (Rivix 2004). RiverTools provides a specialized set of tools for the analyses of topography, watersheds and river networks. For instance, RiverTools makes it easy to get accurate measurements for things like the lengths and slopes of channel segments, the number of streams of a given order, the contributing area of a catchment, the shape of a longitudinal profile, a basin's hypsometric curve, topographic wetness indices, the shape of a catchment and many others.

\section{Results and Discussion}

\subsection{Sediment yields in NW Greece as compared to universal measurements}

The application of the mean daily discharges to the sediment rating curves are resulting in the values of mean annual sediment yield $\left(\mathrm{S}_{\mathrm{Y}}\right)$ and mean annual sediment discharge $\left(\mathrm{Q}_{\mathrm{s}}\right)$. The corresponding values as well as the catchment area, the mean annual discharge and the mean annual maximum flood (in terms of mean daily discharges) are presented in Table 1.

For almost the same cross sections, estimates of mean annual sediment discharges have been issued from the PPC and also from Koutsoyiannis and Tarla (1987) and Poulos and Chronis (1997).

Figure 3 presents a comparison of the published estimates of the mean annual sediment discharge between the present paper and the ones from the PPC, Koutsoyiannis and Tarla (1987) and Poulos and Chronis (1997). It is shown that in almost all the cases all the published estimates are quite different. Zarris et al. (2006) showed that the inconsistency of sediment yield estimates might provoke an underestimate of the dead storage volume of the Ag. Demetrios Reservoir (Evinos River; upstream of the Poros Riganiou gauging station) and an overestimate of the corresponding volume of the Messochora Reservoir (Acheloos River; upstream of the Avlaki gauging station). 
The present study actually presents significantly higher sediment yields of the Acheloos and Evinos Rivers and less of the Kalamas and Aracthos Rivers. Generally it is often surprising how different sediment yield estimates are derived from nearly the same set of original data. This is in general explained by the serious complexity of the processes involved from the computation of the mean daily discharges to the adequate interpretation of the sediment discharge measurements in order to construct the adequate rating relationship between sediment and stream discharge. However, simultaneous measurements of river and sediment discharge are mainly conducted only in low - flow periods, thus any extrapolation for wash loads at the time of low frequency - high magnitude flood flows will generally give misleading results, unless a correct slope of the rating curve is estimated.

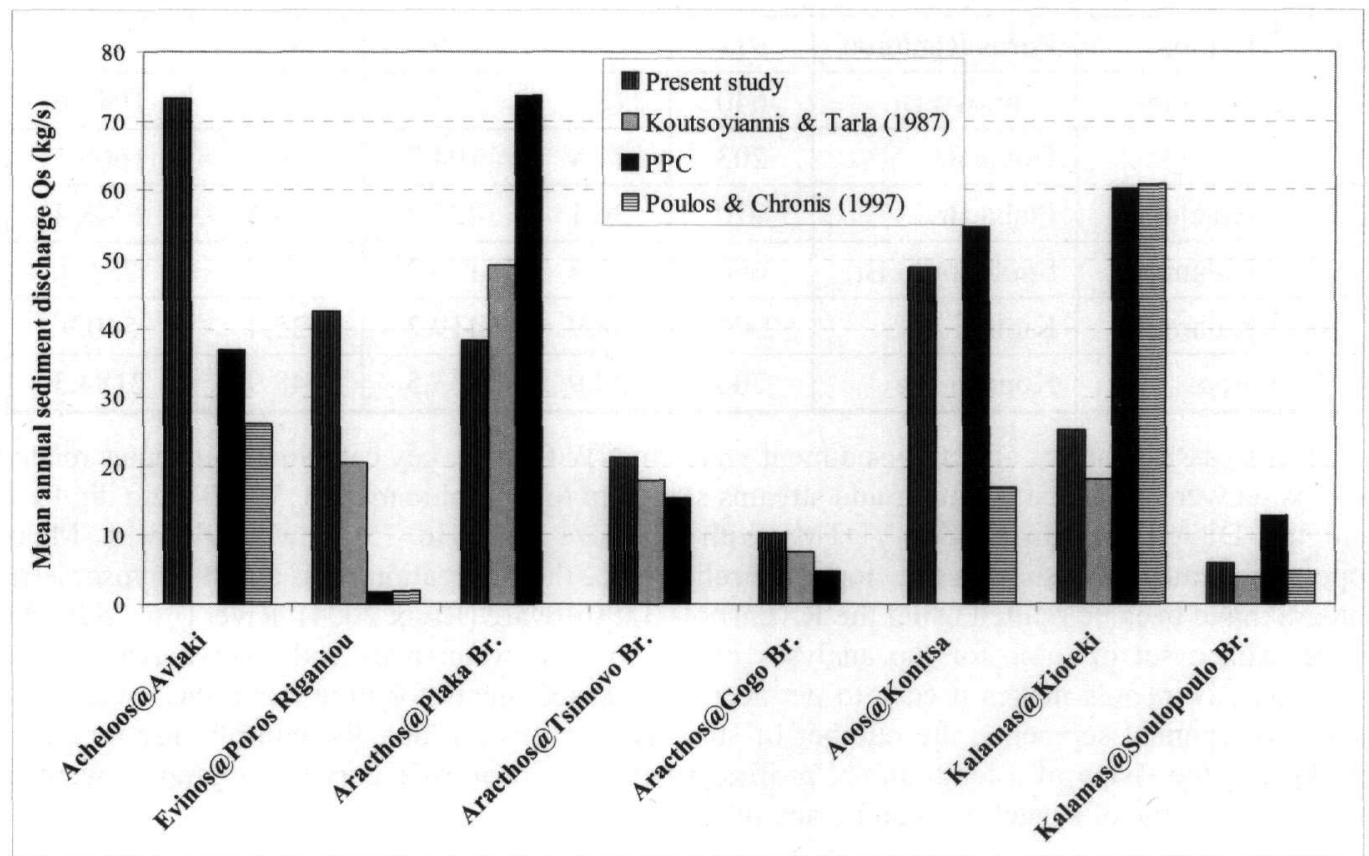

\section{Figure 3 - Comparison of sediment yield estimates in NW Greece as compared with different references}

According to our results from the 11 river sites in NW Greece and the data bank with sediment yield measurements from around the globe (823 catchments) that the first of the authors has collected from numerous publications, the box plots of the sediment yields are presented in Figure 4. These circles are filled in when the values are more than three times the distance between the quartiles $\left(\mathrm{Q}_{75 \%}-\mathrm{Q}_{25 \%}\right)$ otherwise they are empty. It is evident that the highest sediment yields in the world are found in Asia with mean value around $2000 \mathrm{t} / \mathrm{km}^{2} / \mathrm{a}$. It is also shown that a lot of catchments in Asia exhibit sediment yields in excess of $6000 \mathrm{t} / \mathrm{km}^{2} / \mathrm{a}$. The estimated sediment yields in our study naturally are higher than those measured in the rest of Europe (mostly from the northern Europe) and from the Americas, largely because tectonic activity seriously affects the sediment yield of such catchments. Furthermore, rivers that drain active edges of continental margins (e.g., western South and North America) or collision margins (e.g., southern Europe and southern Asia) are generally much smaller, but collectively they transport similar amounts of sediment as do large passive margin rivers. It is also evident that the small number of sediment yield estimates in NW Greece does not allow for arbitrary generalizations. 


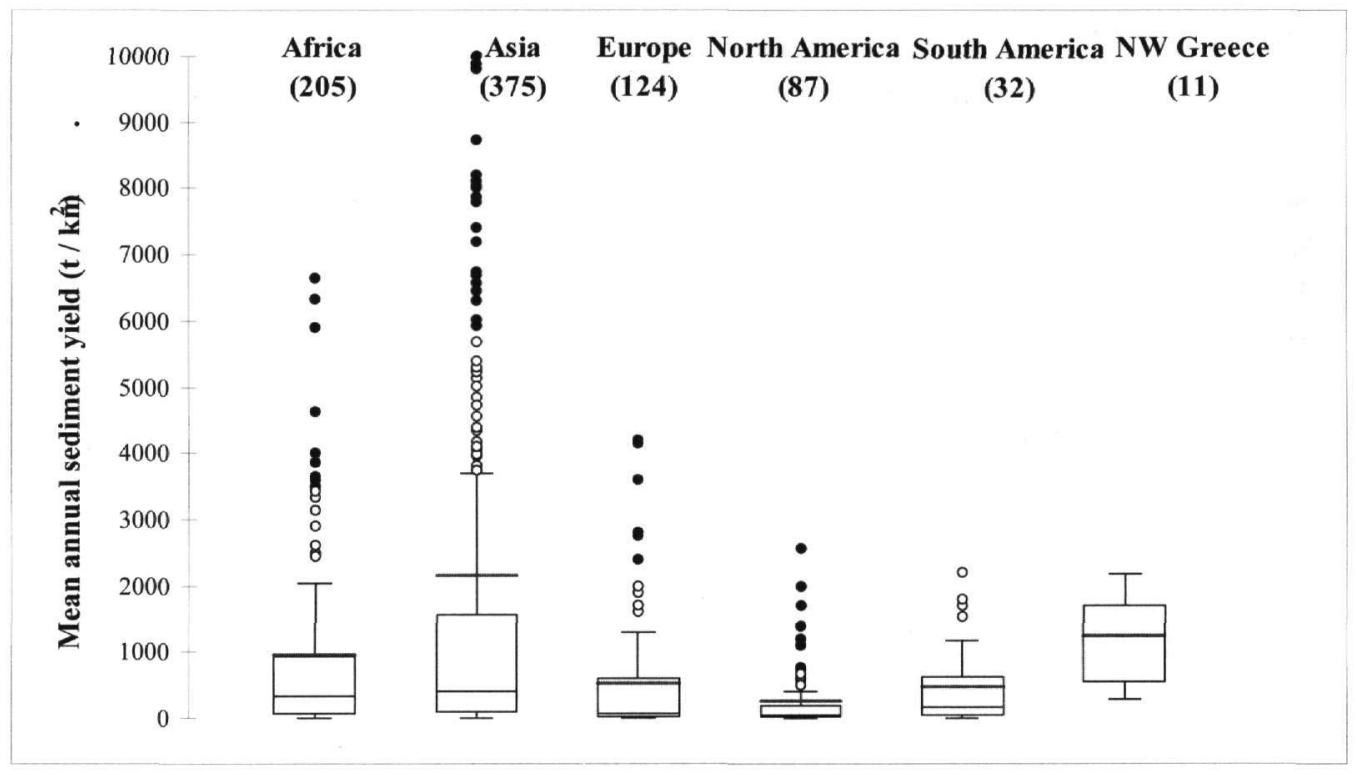

\section{Figure 4 - Box plots of global sediment yield measurements as compared to those from NW Greece (number of catchments in parentheses)}

Influence of hydrologic parameters

Figure 5 presents the correlation of mean annual sediment discharge with catchment area. The correlation is weak $\left(\mathrm{R}^{2}=0.39\right)$, which means that catchment area, although is a key element in sediment transport, cannot alone describe adequately the complex physical processes. On the other hand, (Figure 6), the mean annual flood (see also Table 2) has an excellent correlation with mean annual sediment discharge $(\mathrm{R}=0.91)$ while the correlation with mean annual discharge is not at the same level $(\mathrm{R}=0.61)$. It is evident that sediment discharges are computed as a function of discharge; so that the mean annual sediment discharges will be highly dependent on the river discharge. The better correlation with the mean annual flood as compared to the mean annual discharge is explaining the fact that the vast majority of the annual sediment yield is transported during few floods during a given year. The apparent difficulty to collect all the available rainfall data for such large catchment scales for the period when the sediment discharge measurements have been carried out prevented the introduction of rainfall into our analyses. This will be done in later stages of this research.

\subsection{Influence of geomorphologic parameters}

It is extremely rare in the international literature to come across with correlation equations between sediment yield and certain geomorphologic parameters. However, Tamene et al. (2006), presented an excellent review on the effect of the geomorphologic variables to the sediment yield measurements in Ethiopia. They found that the development of gullies are primarily responsible for the high sediment yields in the area and produced an index, called Standardized Bank Collapse and Bank eRosion (SBCR) index, for the qualitative description of the gully development within the catchment. 


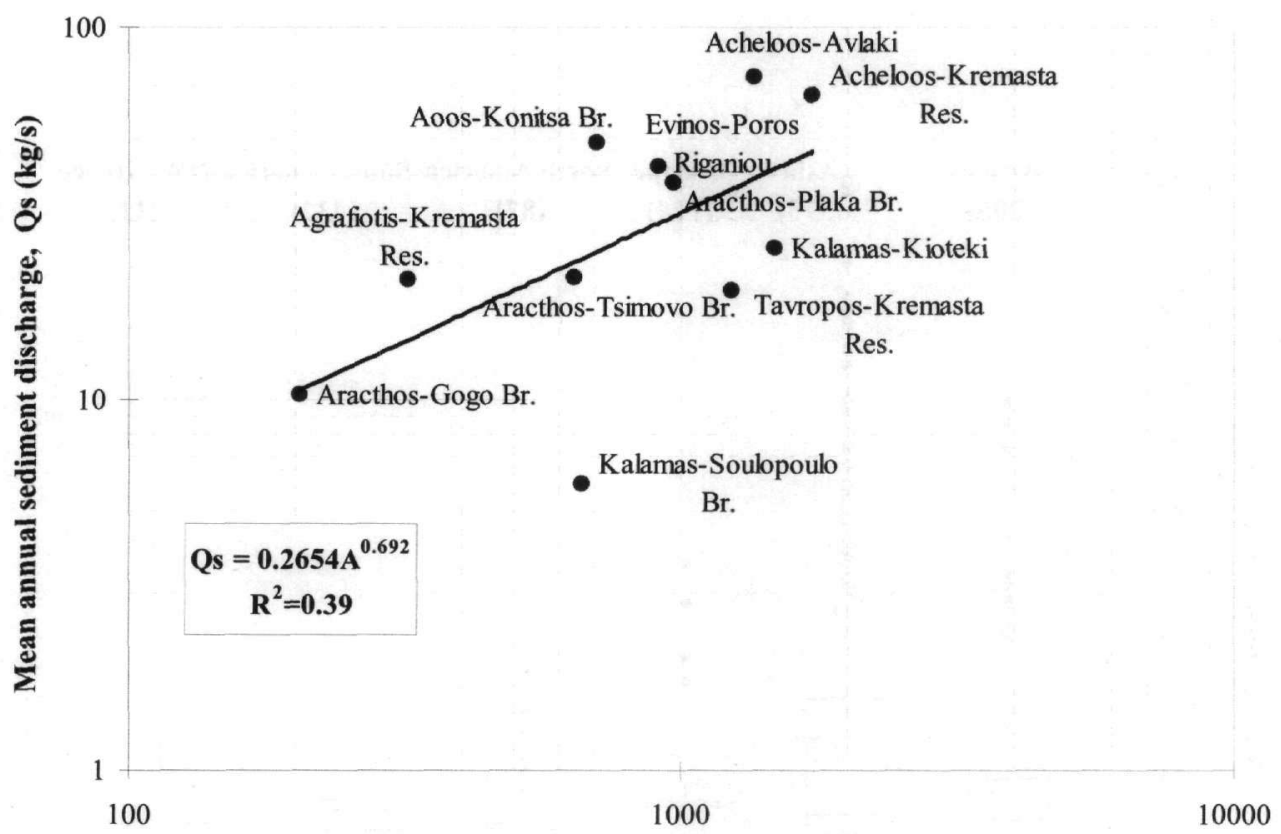

Catchment Area, $\boldsymbol{A}\left(\mathrm{km}^{2}\right)$

Figure 5 - Relation between mean annual sediment discharge with catchment area

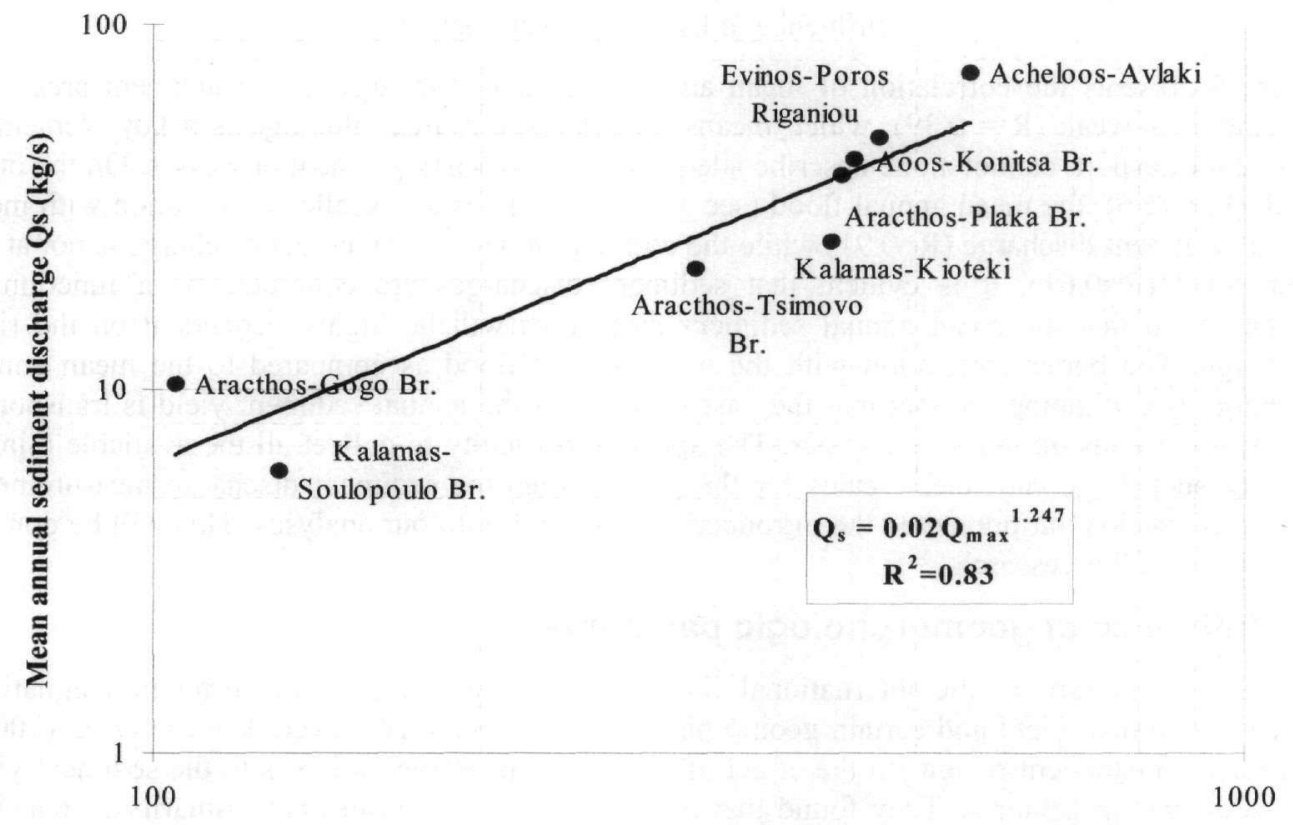

Mean annual flood $Q_{\max }\left(\mathrm{m}^{3} / \mathrm{s}\right)$

Figure 6 - Relation between mean annual sediment discharge and mean annual flood 
Table 2 presents the examined geomorphologic parameters under consideration with a synoptic explanation of the role of each parameter in conceptualizing sediment yield processes and the correlation coefficients with the sediment yield estimates. In bold characters, the most influential parameters are being denoted. The bifurcation ratio, for instance, is by no means involved in any empirical (statistical) regression relations with sediment yield in the international literature, according to the authors' knowledge. It is included, however, in statistical relations with catchment sediment delivery ratio, DR, (i.e. the proportion of eroded sediment that finally reaches the catchment's outlet).

Roehl (1962) using sediment yield data from 15 catchments from the Southeast USA and source erosion estimates derived from the Universal Soil Loss Equation (USLE), stated that the catchment's delivery ratio is computed by the equation: (reprinted from McCuen 1998, p. 795):

Equation 2: Relation of sediment delivery ratio with geomorphologic characteristics (Roehl, 1962)

$$
D R=18620 A^{-0.23}\left(\frac{L}{R}\right)^{-0.51} R_{B}^{-2.79}
$$

where $L=$ watershed length; and $R=$ watershed relief (or the elevation difference), all in English units and $D R$ expressed as a percentage. The concept of delivery ratio might be valuable in conceptualizing sediment yield processes but is highly uncertain in its application. Indeed, source erosion is at least as difficult to be computed (usually with the USLE) as the sediment yield itself. Equation 2 implies that the bifurcation ratio is inversely proportional to the catchment sediment yield. It is supposed that higher bifurcation ratios are likely to reveal elongated catchments with long, thin drainage networks that forces sediment to deposit within the stream network, especially if moderate magnitude flood events are prevailing and/or the vegetation cover is dense. However, Lykoudi and Zarris (2004) presented preliminary evidence that this statement does not hold and apparently the $R_{\mathrm{B}}$ should be proportional to the sediment yield. This was verified with the nonlinear correlation analysis shown in Equation 3, where mean annual sediment yield is proportional to the $R_{\mathrm{B}}$, the Hypsometric Integral and the USLE's K-factor. The coefficient of determination (after testing several combinations with other physically independent parameters) ensures that the equation explain the $74 \%$ of the observed variance in the dataset.

Equation 3: Correlation of mean annual sediment yield with the Hypsometric Integral (HI), Bifurcation Ratio $\left(\mathbf{R}_{\mathbf{B}}\right)$ and USLE Soil Erodibility Factor $(\mathrm{K})$

$$
S_{y}=40.23 * H I^{1.06} * R_{B}^{1.40} * K^{0.59} \quad \mathrm{R}^{2}=0.74
$$

In the stream networks under consideration, the mean bifurcation ratio is around 4.2 , which is almost two times the ideal value of $\mathrm{R}_{\mathrm{B}}=2.0$ (Strahler 1952) and marginally higher of the corresponding «theoretical» value $\left(\mathrm{R}_{\mathrm{B}}=4.0\right)$ (Leopold and Langbein 1962, Shreve 1966) of a stream network which is in a state of dynamic equilibrium. The high values of $R_{B}$ is mainly ascribed to the high slopes of the terrain, due to the neo-tectonic activity, which results in a significant development grade of the stream network.

This illustrates the fact that the stream networks under consideration are in a state of dynamic equilibrium with a tendency of further sediment transport and erosion than of deposition. In catchment with higher bifurcation ratios sediment yield is also higher. This is due to the fact that lower order streams that are joined into higher order streams are more in absolute numbers than those according to the ideal values. This results in the case where the sediment availability is higher than the transport capacity of the higher order streams. Equation 4 shows that the mean annual sediment discharges are proportional to the catchment length and inversely proportional to the catchment's drainage density, explaining the $83 \%$ of the variance of the data set. The inverse 
proportionality with the drainage density, although it seems that has no physical meaning, will be further explored in later stages of our research.

Equation 4: Correlation of mean annual sediment discharge with the Catchment Length (Lbmax) and Drainage Density (DD)
$Q_{s}=173.4 * L b_{\max }^{0.76} * D D^{-3.6}$
$\mathrm{R}^{2}=0.79$

Table 2 - Major terrain characteristics and their relation to erosion and transport processes

\begin{tabular}{|c|c|c|c|}
\hline \multirow[b]{2}{*}{ Geomorphologic parameter } & \multirow{2}{*}{$\begin{array}{l}\text { Influence on erosion and } \\
\text { transport processes }\end{array}$} & \multicolumn{2}{|c|}{ Correlation Coefficients } \\
\hline & & $\begin{array}{l}\text { Sediment } \\
\text { Yield Sy }\end{array}$ & $\begin{array}{c}\text { Sediment } \\
\text { Discharge Qs }\end{array}$ \\
\hline Catchment Area (A) & Global parameter & -0.41 & 0.49 \\
\hline Mean annual discharge $\left(Q_{a v}\right)$ & Runoff Potential & 0.12 & 0.61 \\
\hline Mean annual flood $\left(Q_{\max }\right)$ & $\begin{array}{l}\text { Stream Power, Transport } \\
\text { Potential }\end{array}$ & 0.43 & 0.91 \\
\hline Hypsometric Integral (HI) & $\begin{array}{l}\text { Distribution of elevation with } \\
\text { catchment }\end{array}$ & 0.75 & 0.35 \\
\hline Catchment Length $\mathrm{Lb}_{\max }$ & Catchment size index & 0.25 & 0.75 \\
\hline Mean Slope & Flow velocity and momentum & 0.31 & -0.28 \\
\hline Drainage Density (DD) & $\begin{array}{l}\text { Balance between erosive } \\
\text { forces and surface resistance }\end{array}$ & -0.57 & -0.74 \\
\hline Drainage Frequency (DF) & $\begin{array}{l}\text { Stream network texture, } \\
\text { Relief disruption }\end{array}$ & -0.27 & -0.62 \\
\hline Circularity Index (CI) & \multirow{2}{*}{$\begin{array}{l}\text { Rate of sediment delivery, } \\
\text { deposition potential }\end{array}$} & 0.23 & -0.47 \\
\hline Elongation Ratio (ER) & & -0.60 & -0.52 \\
\hline Bifurcation Ratio $\left(\mathrm{R}_{\mathrm{B}}\right)$ & $\begin{array}{l}\text { Internal processes index, } \\
\text { branches development grade, } \\
\text { stream network dynamic } \\
\text { equilibrium }\end{array}$ & 0.69 & 0.00 \\
\hline Relief Ratio (RR) & Intensity of erosion process & -0.31 & -0.63 \\
\hline $\begin{array}{l}\text { USLE Soil Erodibility Factor } \\
(\mathrm{K})\end{array}$ & $\begin{array}{l}\text { Main source of erosion } \\
\text { processes }\end{array}$ & 0.66 & 0.27 \\
\hline
\end{tabular}

\section{Conclusions}

The main scope of the research presented in this paper is to compute the mean annual sediment yield and discharge for eleven river cross-sections in NW Greece. The basic data were the sediment discharge measurements and the mean daily stream discharges, all available from the PPC. Sediment discharge was statistically associated with the simultaneous river discharge, namely the sediment discharge-rating curve, by means of the broken line interpolation method that represents realistically the process of the break up of the armour layer in gravel-bed rivers when a certain discharge threshold is exceeded. Then mean daily sediment discharges were computed from the mean daily stream discharges and the mean annual sediment discharge is finally estimated. The cornerstone of this approach is the correspondence of the mean annual sediment discharge of Acheloos River at Avlaki gauging station computed by the broken line rating curve 
with the corresponding value computed by the sediment deposits in the Kremasta Reservoir located just downstream of the Avlaki gauging station (Zarris and Koutsoyiannis 2005)

Certain geomorphologic parameters have been computed from the catchments' DTMs and their values were introduced in non-linear correlation analyses with the mean annual sediment yield and discharge. Two equations with high values of the coefficient of determination have been calculated in order to, at least, qualitatively describe the phenomena in terms of the relation between sediment yield and catchment geomorphology.

\section{Acknowledgments}

This paper is a result of the research program “Assessment of hydrologic catchments' sediment yield by comparative analyses of hydrologic and geomorphologic parameters", which is funded from the National Technical University of Athens under the framework program of basic research "PROTAGORAS". The authors are also indebted in the Public Power Corporation for providing the sediment discharge data.

\section{References}

Asselman, N.E.M., 2000. Fitting and interpretation of sediment rating curves, Journal of Hydrology, 234, 228-248.

Dendy, F.E., and Bolton, G.C., 1976. Sediment yield-runoff drainage area relationships in the United States, J. Soil and Water Cons., 31, 264-266.

de Vente, J., Poesen, J., and Verstraeten, G., 2005. The application of semi-quantitative methods and reservoir sedimentation rates for the prediction of basin sediment yield in Spain, Journal of Hydrology, 305, 63-86.

Ferguson, R.I., 1986. River loads underestimated by rating curves, Water Resources Research, 22 (1), 74-76.

Jansen, J.M.L., and Painter, R.B., 1974. Predicting sediment yield from climate and topography, Journal of Hydrology, 21, 371-380.

Koutsoyiannis, D., and Tarla, K., 1987. Sediment yield estimations in Greece, Technika Chronika, A 7 (3), 127-154. (in Greek)

Koutsoyiannis, D., 2000. Broken line smoothing: a simple method for interpolating and smoothing data series, Environmental Modelling \& Software, 15, 139-149.

Leopold, L.B., and Langbein, W.B., 1962. The concept of entropy in landscape evolution, U.S.G.S. Prof. Paper 500-A, 1-20pp.

Lykoudi, E., and Zarris, D., 2004. The influence of drainage network formation and characteristics over a catchment's sediment yield, Proceedings, Second International Conference on Fluvial Hydraulics - RiverFlow 2004, University of Napoli - Federico II, Naples, Italy, 2325 June, 793-800pp.

McCuen, R.H., 1989. Hydrologic Analysis and Design, Englewood Cliffs. New Jersey: Prentice Hall.

Poulos, S.E., and Chronis, G.Th., 1997, The importance of the river systems in the evolution of the Greek coastline, In Transformations and evolution of the Mediterranean coastline, Bulletin de l' Institute Oceanographique, Monaco, (18), 75-96.

Rivix, 2004., RiverTools 3.0 - User Guide, 218pp, USA. 
Roehl, J.W., 1962. Sediment source areas, delivery ratios and influencing morphological factors, International Association of Hydrological Sciences Publication, no. 59, 202-213.

Shreve, R.L., 1966. Statistical law of stream numbers, Journal of Geology, 74, 17-37.

Strahler, A., 1952. Hypsometric (area-altitude) analysis of erosional topography, Geol. Soc. Amer. Bull., 63, 1117-1142.

Tamene, L., Park, S.J., Dikau, R., and Vlek, P.L.G., 2006. Analysis of factors determining sediment yield variability in the highlands of northern Ethiopia, Geomorphology, 76, 76-91.

Verstraeten, G., and Poesen, J., 2000. Estimating trap efficiency of small reservoirs and ponds; an overview of existing methods and the implications for the assessment of sediment yield, Progress in Physical Geography, 24(2), 219-251.

Walling, D.E., 1977. Assessing the accuracy of suspended sediment rating curves for a small basin, Water Resources Research, 13 (3), 531-538.

Walling, D.E., 1983. The sediment delivery problem, Journal of Hydrology, 65, 209-237.

Zarris, D., Lykoudi, E., and Koutsoyiannis, D., 2002. Sediment yield estimation from a hydrographic survey: A case study for the Kremasta reservoir basin, Greece, Proc. of the 5th International Conference "Water Resources Management in the Era of Transition", Athens, 4-8 September, 338-345pp.

Zarris, D., and Koutsoyiannis, D., 2005. Evaluating sediment yield estimations from large-scale hydrologic systems with the rating curve concept, RMZ-Materials and Geoenvironment, 52 (1), 157-159

Zarris, D., Lykoudi, E., and Panagoulia, D., 2006. Assessing the impacts of sediment yield on the sustainability of major hydraulic systems, International Conference "Protection and Restoration of the Environment VIII", 3 - 7 July 2006 Chania, Greece. 